GRASAS Y ACEITES 70 (1)

January-March 2019, e289

ISSN-L: 0017-3495

https://doi.org/10.3989/gya.0580181

\title{
Geographic variation in fatty acid composition and food source of the commercial clam (Venerupis decussata, Linnaeus, 1758), from the Tunisian Coast: Trophic links
}

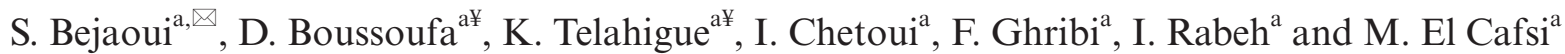 \\ ${ }^{a}$ Unit of Physiology and Aquatic Environment, Biology Department, Faculty of Science of Tunis, University of Tunis El Manar, \\ 2092, Tunis, Tunisia. \\ $¥$ These authors contribute equally to this work \\ ${ }^{\otimes}$ Corresponding author: safa.bejaoui@fst.utm.tn
}

Submitted: 25 May 2018; Accepted: 26 July 2018

SUMMARY: Lake and coastal Tunisian areas are rich biodiversity habitats, although little information is available about the distribution of food sources for the inhabitant species. In this study, a fatty acid analysis was used to study the trophic ecology of Venerupis decussatac ommunities from 10 sites located along the Tunisian Coast. The richest population in fatty acids was found in S4 followed by S5 and S8, while that of S1, S3 and S10 were the least rich. Results from multivariate analysis confirmed the ecological position of the studied population based on their fatty acid composition. Our results divided the ten studied populations into three similar groups according to their ecological and geographical positions in relation to environmental parameters and food and trophic links. A principal component analysis revealed that diatoms and dinoflagellates were the predominate diets in all the sampling stations. Bacteria and urban discharge dominated the dietary source of clams from S10 and S9. Zooplankton were the preferred diet of $V$. decussata harvested from the two S2 and S3 lakes; although green algae, phytoplankton and detritus were absent from the dietary source of the two previous populations. Despite spatial differences, clams from the north and the south could be easily distinguished from each other, which indicates the utility of this method in the dietary analysis of different food chain links. This study proves that geographic, ecologic and abiotic factors as well as their mutual interaction should be properly investigated in studies focusing on the trophic chains of aquatic ecosystems.

KEYWORDS: Estuary and coastal lagoons; Fatty acid composition; Multivariate analysis; Trophic links; Tunisian waters; Venerupis decussata

RESUMEN: Variación geográfica en la composición de ácidos grasos y fuente de alimento de la almeja comercial (Venerupis decussata, Linnaeus, 1758), de las costas tunecinas: cadenas tróficas. Los lagos y las zonas costeras de Túnez son ricos en hábitats de biodiversidad. Sin embargo, hay poca información disponible sobre la distribución de las fuentes de alimentos para las especies residentes. En este trabajo se utilizó el análisis de ácidos grasos para estudiar la ecología trófica de las comunidades de Venerupis decussata de 10 localizaciones a lo largo de las costas tunecinas. La población más rica en ácidos grasos se encontró en S4 seguida de S5 y S8, mientras que la de S1, S3 y S10 fueron las menos ricas. Los resultados del análisis multivariante confirmaron la posición ecológica de la población estudiada en función de su composición de ácidos grasos. Nuestros resultados dividieron las diez poblaciones estudiadas en tres grupos similares según sus posiciones ecológicas y geográficas en relación con los parámetros ambientales y con los enlaces tróficos y alimentarios. El análisis de los componentes principales reveló que las dietas predominantes eran las diatomeas y los dinoflagelados en todas las estaciones de muestreo. Mientras que, las bacterias y la descarga urbana dominaron la fuente dietética de almejas de S10 y S9. Sin embargo, el zooplancton fue la dieta preferida de $V$. decussata cosechada de los dos lagos S2 y S3; las algas verdes, el fitoplancton y los detritos estaban ausentes en la fuente dietética de las dos poblaciones anteriores. A pesar de las diferencias espaciales, las almejas del norte y del sur se pueden distinguir fácilmente entre sí, lo que indica la utilidad de este método en el análisis dietético de los diferentes enlaces de la cadena alimentaria. Este estudio demuestra que los factores geográficos, ecológicos y abióticos, así como su interacción mutua deben investigarse adecuadamente en estudios centrados en las cadenas tróficas de los ecosistemas acuáticos.

PALABRAS CLAVE: Aguas tunecinas; Análisis multivariable; Composición de ácidos grasos; Enlaces tróficos; Estuario y lagunas costeras; Venerupis decussata

ORCID ID: Bejoui S https://orcid.org/0000-0002-7946-2763, Boussefa D https://orcid.org/0000-0003-4316-1616, Telahigue K https://orcid.org/0000-0001-8841-9911, Chetoui I https://orcid.org/0000-0002-2259-5397, Ghribi F https://orcid.org/0000-0001-9350-7510, Rabeh I https://orcid.org/0000-0002-0307-473X, El Cafsi M https://orcid. org/0000-0002-9771-1110

Citation/Cómo citar este artículo: Bejoui S, Boussefa D, Telahigue K, Chetoui I, Ghribi F, Rabeh I, El Cafsi M. 2019. Geographic variation in fatty acid composition and food source of the commercial clam (Venerupis decussata, Linnaeus, 1758), from the Tunisian Coast: Trophic links. Grasas Aceites 70 (1), e289. https://doi.org/10.3989/gya.0580181

Copyright: (C2019 CSIC. This is an open-access article distributed under the terms of the Creative Commons Attribution 4.0 International (CC BY 4.0) License.

ABBREVIATIONS: Venerupis decussata ( $V$. decussata); Polyunsaturated fatty acids (PUFA); Monounsaturated fatty acids (MUFA); Saturated fatty acids (SFA); Total fatty acids (TFA); Eicosapentaenoic (EPA); Docosahexaenoic (DHA); Arachidonic acid (ARA); Temperature $\left(\mathrm{T}^{\circ} \mathrm{C}\right)$; Salinity (S psu); Chlorophyll a (Ch a); Suspended matter (SPM). 


\section{INTRODUCTION}

The littoral of Tunisia covers $1300 \mathrm{Km}$; it possesses an important particular biodiversity and is considered the richest ecosystem in the Mediterranean Sea (Hattour and Ben Mustapha, 2013). This ecosystem is situated in the most productive area in the Mediterranean Sea, and its high productivity is maintained by a great level of nutrients in both sediment and water column. These transition zones between land and sea can offer unique ecosystem services ranging from trapping contaminants in their sediments to providing nursery areas for marine species and feeding grounds for migratory birds (McLusky and Elliot, 2004). All these specificities provide the littoral of Tunisia with a particular marine and coastal biodiversity.

In fact, the study of the biological functions of marine organisms, as well as seafood quality/quantity, in relation to the surrounding environment, has always been the matter of investigation in different scientific areas such as environmental ecotoxicology and food chemistry (Albergamo et al., 2016; Gomes et al., 2017). However, to comprehend how the stability of a marine ecosystem tolerates it, an analysis of the feeding associations among organisms, especially filter species like bivalves, is very important. In fact, FA analyses have been used extensively to study trophic relationships and as important determinants of ecosystem health and stability in marine food webs (Dalsgaard et al., 2003; Budge et al., 2006).

Bivalves, especially, $V$. decussata, are present at high densities along the sandy beaches of the Tunisian Coast, and they are one of the most important commercial species. This species is considered a potential candidate for shellfish farming in this area. Like others bivalves (Pagano et al., 2016) $V$. decussata are filter-feeders, and consume the phytoplankton suspended in the water column (Hamida et al., 2004). Their ecological and biological preferences have been studied extensively along the Mediterranean Coast (Hamida et al., 2004; Bejaoui et al., 2017). Notwithstanding their position, the nutritional resources and trophic associations of these plentiful groups are inadequately studied. Recent studies analyzing the trophic relationships in marine food chains have been carried on the FA signature to indicate their distribution and preference (Parrish et al., 2015). However, no data about feeding strategies or trophic links of bivalves taken from the Tunisian waters have been reported. In contrast, other international research based on fatty acid composition has been widely used to determine the trophic link between benthic bivalves and primary producers (Irisarri et al., 2014; Kharlamenko et al., 2015). Other studies carried out on spatial and environment changes in food composition have been reported in several aquatic bivalves harvested from different localities, such as Mytilus galloprovincialis and Crassostrea gigas from the Thau Lagoon (Pernet et al., 2012) and Glauconome chinensis, Sinonovacula constricta from Yangtze Estuarine Intertidal Marsh (Wang et al., 2015).

The current study constitutes a novel investigation on the relationship between the fatty acid composition and the trophic marker of the European clam $V$. decussata and its geographic repartition in the inshore Tunisian area.

The objectives of this study were, then, to answer several questions:

- Does the fatty acid composition of this species vary among geographically different locations?

- Are there any similarities in the quality of the diet supplied by different locations to the same species $V$. decussata?

- Does $V$. decussata have a selective choice for its food?

\section{MATERIALS AND METHODS}

\subsection{Sampling procedures}

Specimens of $V$. decussata (mean total weight: $8.19 \pm 0.717 \mathrm{~g}$; mean total length: $38.25 \pm 5.45 \mathrm{~mm}$; $\mathrm{n}=50$ per sites) were sampled by hand fishing on foot or by scuba diving, at ten different commercial fishing sites along the Tunisian Coast (Figure 1 and Table 1), during the winter season, 2015. The sampling sites were: Bizerte Lagoon (S1); North Lake (S2); South Lake (S3); Louza (S4); Zabbousa (S5); Bousaid (S6); Bounglow (S7); Maoumma (S8); Zarrat (S9) and Boughrara Lagoon (S10). The harvested samples were immediately transported to the laboratory in ice boxes. The clams were then kept in filtered sea water flow-through aquaria for at least $24 \mathrm{~h}$ to depurate their gut before being dissected. This procedure ensured the overall expulsion of ingested food accumulated in the midgut (Boussoufa et al., 2011). For each site, the soft tissues of the clams $(35.5 \pm 3.1 \mathrm{~mm}$ anteroposterior shell length) were placed in $-30^{\circ} \mathrm{C}$ for fatty acid analysis. Temperature, salinity and $\mathrm{pH}$ were measured in situ with a thermometer, salinity-conductivity (model: WTW. 800.645.5999) and pH meter (model: WTW.LF.325), respectively. In the laboratory, suspended matter and chlorophyll a were determined according to the Aminot and Chaussepied (1983) methods. In fact, the suspended matter content was obtained by the filtration of $500 \mathrm{~mL}$ of water sample, added at the end of the filtration with $20 \mathrm{~mL}$ of format ammonium in order to remove all traces of salt on the filter. Nucleopore Track-Etch Whatmann filter paper (porosity $0.45 \mu \mathrm{m}$ ) was weighed (dry weight of the front filter filtration) after placing in an oven at $60{ }^{\circ} \mathrm{C}$ for 24 hours. After filtering, the water samples from each station were stored for at 

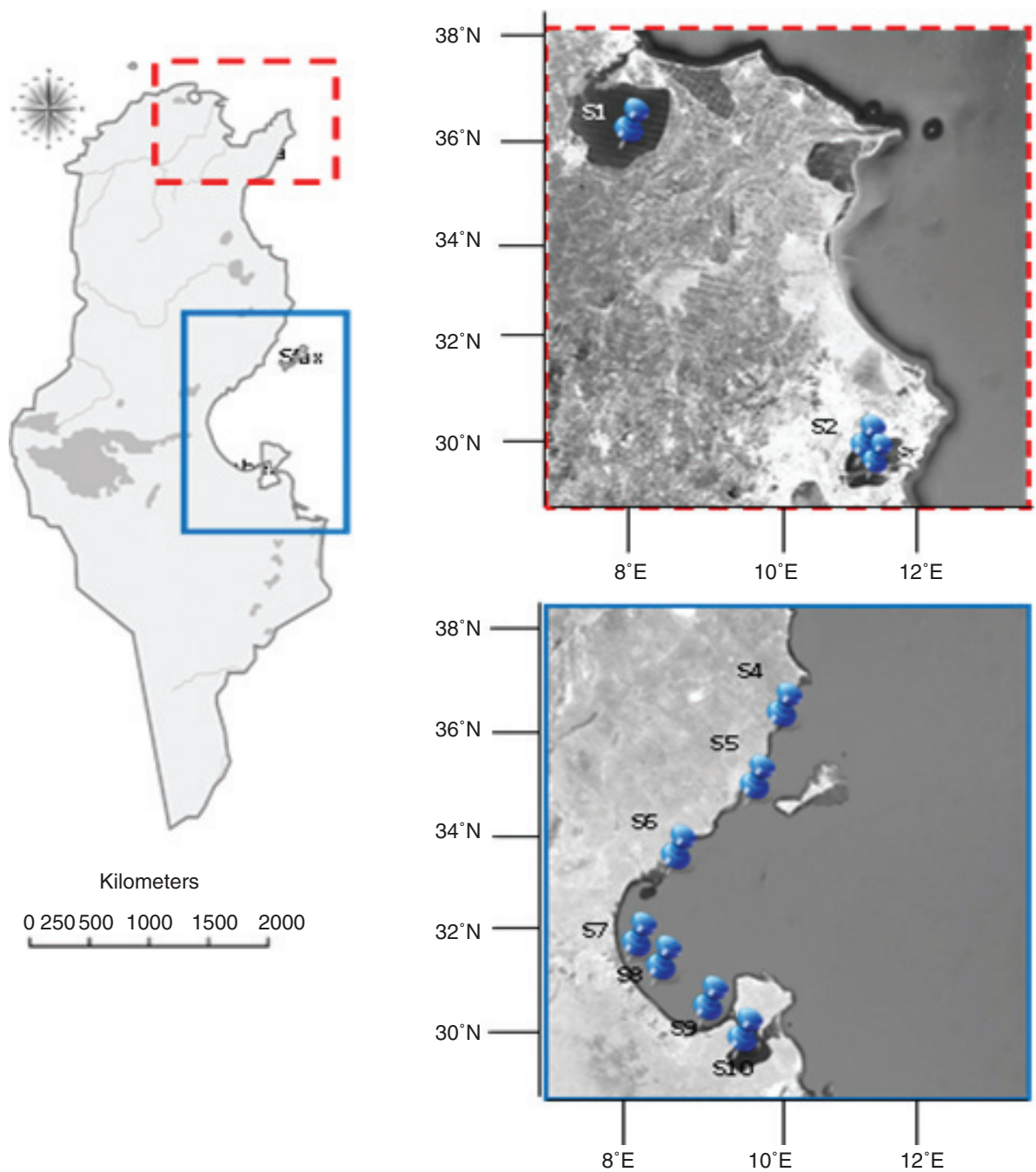

Figure 1. Sampling stations of $V$. decussata along the Tunisian coast.

Bizerte Lagoon (S1), Chekly (S2), Baie (S3), Louza (S4), Zabbousa (S5), Boussaid (S6), Bunglow (S7), Maoumma (S8), Zarrat (S9) and Boughrara Lagoon (S10).

least 48 hours in an oven at $60{ }^{\circ} \mathrm{C}$ to dry. Then the filters were weighed with a precision balance and the dry weight of suspended solids was obtained by subtracting the dry weight of the filter after filtration from the empty one. Finally, the concentration of suspended matter was obtained by dividing by the volume of filtered water.

\subsection{Analysis of the fatty acid composition}

The lipid analysis was carried out on the whole soft body homogenate, extracted with chloroform/ methanol $(2 \mathrm{v} / 1 \mathrm{v})$, containing $0.01 \%$ butylated hydroxytoluene (BHT) as an antioxidant, according to the method of Folch et al., (1957). The lipid content was determined by the gravimetric method and expressed as percent wet weight (WW). The fatty acids (FA) from the total lipids were transmethylated with a solution of sodium methylate and concentrated sulfuric acid solution in methanol (2\%), according to Cecchi et al., (1982). The mixture was centrifuged at $4000 \mathrm{~g}$ for $10 \mathrm{~min}$. The supernatant containing the total fatty acid methyl esters (FAME) was injected into a gas chromatograph equipped with a flame ionization detector and a $30 \mathrm{~m}$ capillary column of flexible silica $250 \mu \mathrm{m}$ in diameter and $0.25 \mu \mathrm{m}$ film thickness (Supelco, PUFA -3). A temperature injector injector of $275^{\circ} \mathrm{C}$ was used, operating in a solvent elimination mode. Nitrogen was the carrier gas. Identification of FAMEs was based on the comparison of their retention times with those of a mixture of methyl esters (SUPELCO PUFA-3), authentic standards (C4 C24 by SUPELCO) and to a well-characterized fish oil (Mehaden oil by SUPELCO). Fatty acid peaks were integrated and analyzed using HP chemstation software. The relative amount of each FA was expressed as $\%$ of total fatty acids ( $\%$ TFA). 
TABLE 1. Characteristics of the sampling locations along the Tunisian waters (Center Mediterranean Sea).

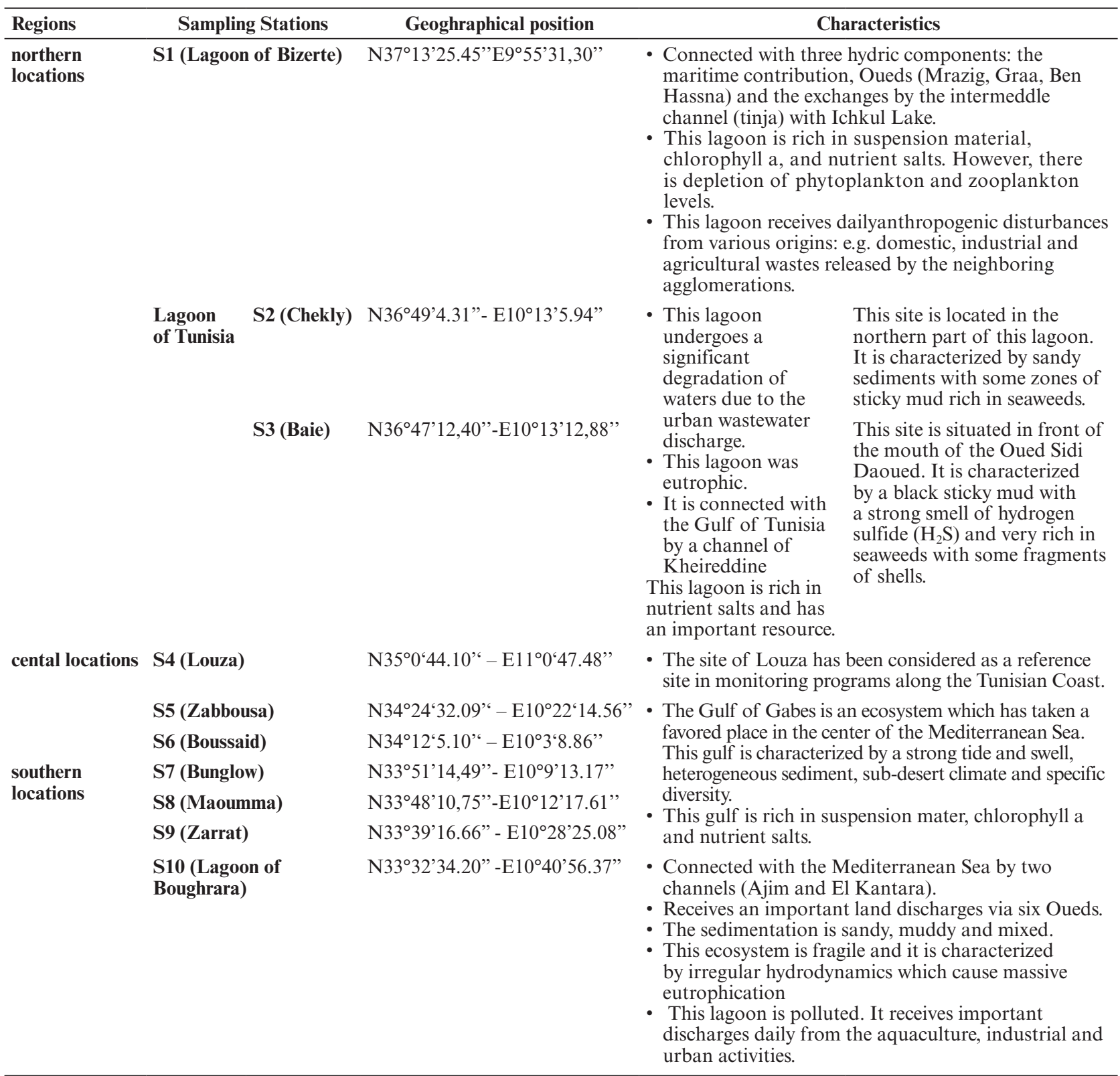

\subsection{Fatty acid trophic marker}

Fatty acid ratios were determined and applied to assess broad clams' food web from the Tunisian Coast. Among them, diatom feeders: $\Sigma 16$, EPA (Dalsgaard et al., 2003); C16:1/C16:0 (Prato et al., 2010) and $\mathrm{C} 18: 1+\mathrm{C} 16: 1 \mathrm{n}-7$ was reported by Auel et al., (2002). Also, C20:1+C22:1 was proposed to reflect the organisms' diet by zooplankton (Parrish et al., 2015). The high proportion of $\mathrm{C} 15: 0+\mathrm{C} 17: 0+\mathrm{C} 18: 1$ denotes the presence of bacteria in the $V$. decussata diet (Budge et al.,2001). A green algae diet was determined by the presence of C16:3; C18:3; C20:4 (Leveillé et al.,1997). The C16:0, C18:4n-3 and high DHA/EPA ratio $(>1)$ reflects the proportion of dino flagellates (Budge et al., 2001; Dalsgaard et al., 2003). PUFAs 22 and HUFAs n-3/n-6 were described by Desvilettes et al., (1997a) and Rocchetta et al., (2014) characterized the detritus feeders. Cyanophyts and phytoplankton were also determined by C16:0, C16:1n-7, C16:4n-3, C18:0 and C18:2n-6 (Li and watanabe, 2001; Irisarri et al., 2014). One other fatty acid trophic marker such as $\mathrm{C} 18: 1+\mathrm{C} 18: 2 \mathrm{n}-6$ was evaluated to esteemed urban discharge (Sakdullah and Tsuchiya, 2009). 


\subsection{Statistical analysis}

All analyses were carried out in ten replicates except fatty acids (triplicate). The results were expressed as mean values \pm standard deviation (SD). A multivariate statistical analysis was performed using Primer 7 software analysis. Similarity, FA composition was checked by the Bray-Curtis test, without a pre-treatment. The impact of individual FAs on the similarities and dissimilarities among sample sites were analysed using the SIMPER analysis. FA groups were identified using the factorial correspondence analysis (FCA). Trophic markers were analysed through the principal component analysis (PCA) using the " $\mathrm{R}$ " software version 2.15.3 (R Core Team, 2012). We further used non-metric multidimensional scaling (NMDS), calculated and plotted in R Vegan library as a multivariate visualization tool for the whole data set. Data were analysed for normality variance homogeneity through the Shapiro test (Sokal and Rohlf, 1987). Post hoc tests of one-way ANOVA followed by Tukey HSD test and non-parametric Kruskal-Walis test for samples with unequal variances were performed so as to investigate significant differences among biochemical parameters. Statistical analyses were performed for a significance level at 0.05 using Statistica (Version 8).

\section{RESULTS}

\subsection{Abiotic factors}

The physicochemical parameters of the ten sampling sites are summarized in Figure 2. During winter, the temperature $\left(\mathrm{T}^{\circ} \mathrm{C}\right)$ and salinity (S psu) ranged from 13 to $17{ }^{\circ} \mathrm{C}$ and from 29 to $35 \mathrm{psu}$, respectively, with significant differences among sites $(p<0.05)$. Chlorophyll a $(\mathrm{Chl}$ a) and suspended material (SPM) followed the same fluctuation within stations with significantly higher values in S2 (northern station: $275.71 \mathrm{mg} / \mathrm{L} ; 1.49 \mu \mathrm{g} / \mathrm{cm}^{3}$ for SPM and Ch a; respectively) and S10 (southern station: $306.26 \mathrm{mg} / \mathrm{L} ; 1.40 \mu \mathrm{g} / \mathrm{cm}^{3}$, for SPM and $\mathrm{Ch}$ a; respectively) $(p<0.05)$ and the lower one in S6 and S7 (southern stations) in the order of 0.82 and $0.69 \mu \mathrm{g} / \mathrm{cm}^{3}$ for SPM and 143.74 and $150.99 \mathrm{mg} / \mathrm{L}$ for Ch a $(p<0.01)$.

\subsection{Fatty acid composition}

In general, PUFAs were present in the highest percentages in all the studied sites, with maximum values recorded in clams from S3 $(40 \%)$ and S4 $(60 \%)$ (Table 2). Among them, linoleic (C18:2n-6) $(>35 \%)$, docosahexaenoic (DHA) $(>13 \%)$, eicosapentaenoic (EPA) $(>6 \%$ ) and arachidonic (ARA) $(6 \%)$ acids had a high range of relative percentage and varied significantly among the sampling stations $(p<0.01)$. Nevertheless, DHA varied significantly in

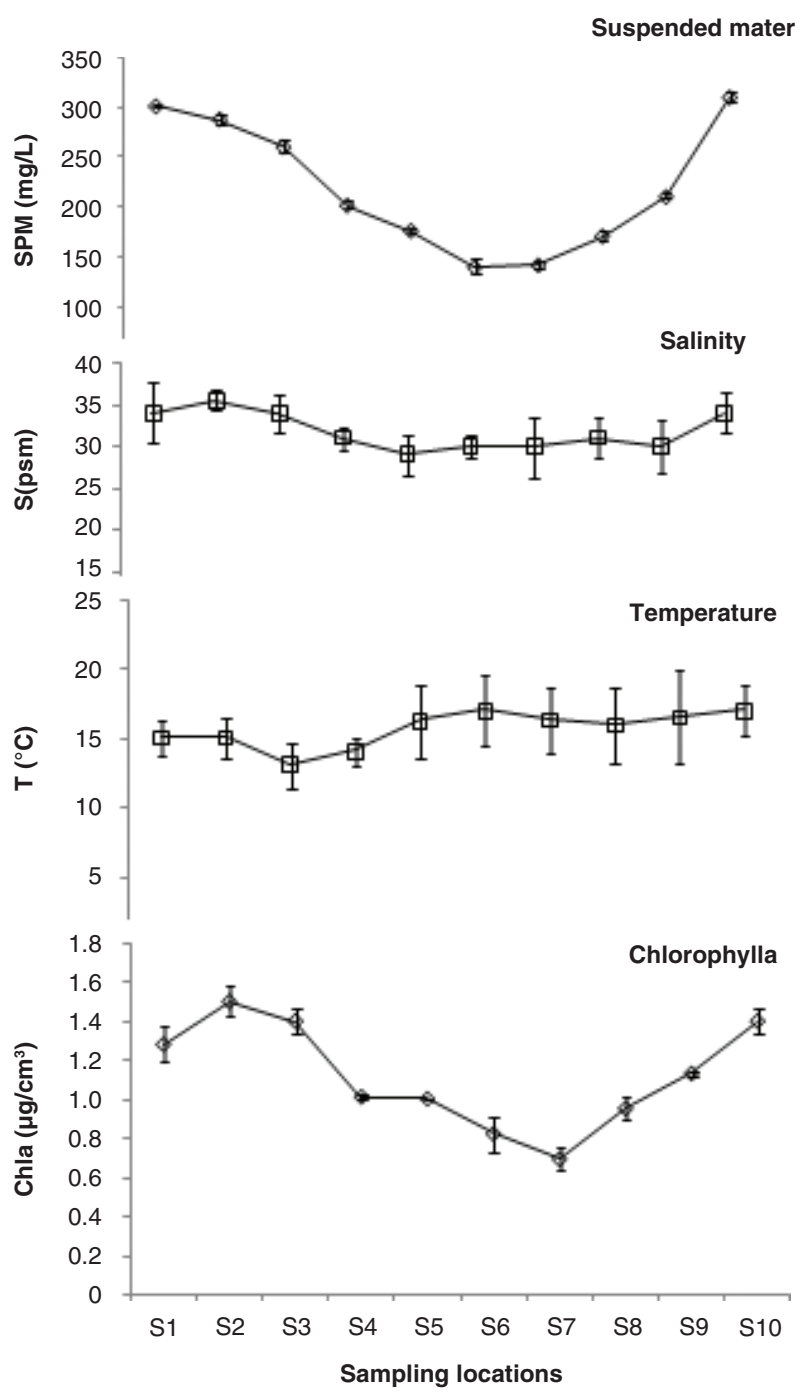

Figure 2. Abiotic parameters of the ten sampled sites along the Tunisian Coast.

Bizerte Lagoon (S1), Chekly (S2), Baie (S3), Louza (S4),

Zabbousa (S5), Boussaid (S6), Bunglow (S7), Maoumma (S8), Zarrat (S9) and Boughrara Lagoon (S10).

Suspended mater (SPM); $\mathrm{T}^{\circ} \mathrm{C}$ (Temperature); Spsu (Salinity); Chlorophyll a (Chl a).

Values are expressed as means \pm SD of three replicates. Significant difference is given by asterisk at $0.05: * \mathrm{p}<0.05$ and $* * p<0.01$ using the ANOVA test (Tukey HSD).

$V$. decussata from the different stations and was the highest in S2 with 13\% of TFA. The lowest percentages were registered in clams from S9 and $\mathrm{S} 10(<2 \%)$ $(\mathrm{p}<0.001)$. Dissimilar variations were recorded for C18:2n-6 with high percentages in specimens from S2 $(1.24 \%)$ as compared to those from S9 and S10 $(>26 \%)$. However, similar trends were observed for the EPA and ARA acid percentages, which presented the highest levels in $V$. decussata from S3 $(6.59 \%$ and $2.90 \%$, respectively) and the lowest levels in the clams from S9 $(0.39 \%$ and $0.81 \%$, respectively) and S10 $(0.65 \%$ and $0.59 \%$, respectively). The notable 


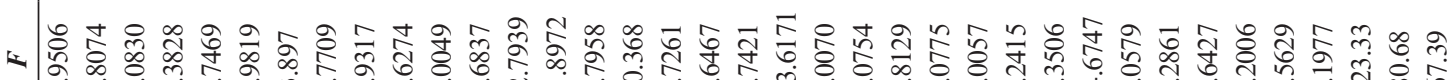
宊仙 jim

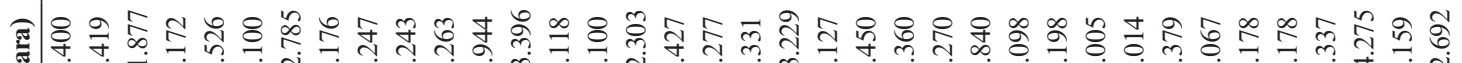

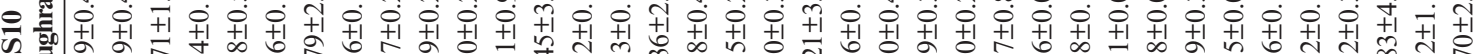

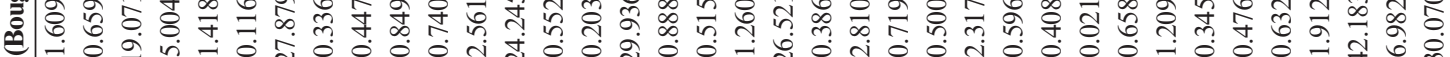

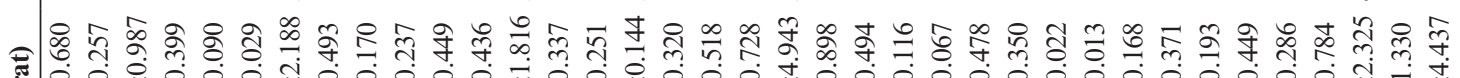

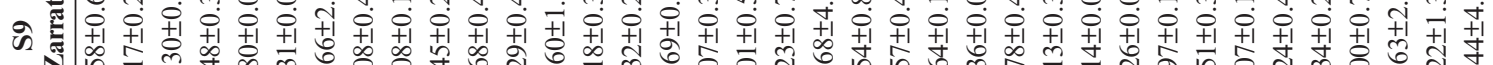

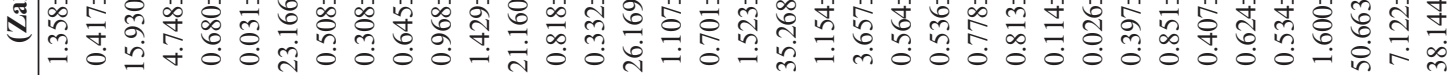

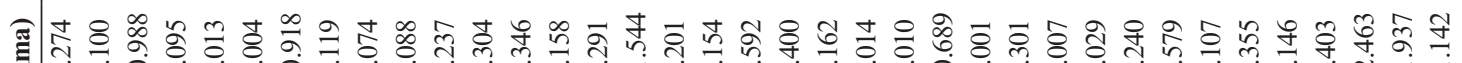

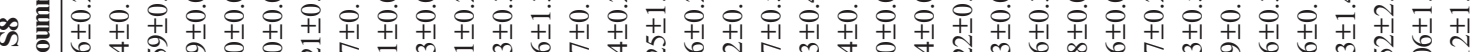

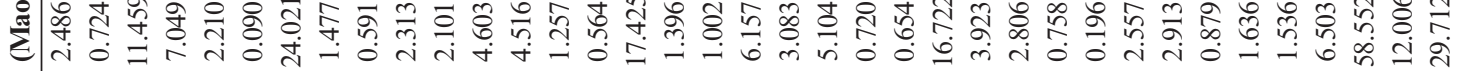

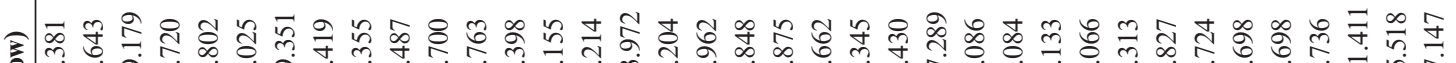

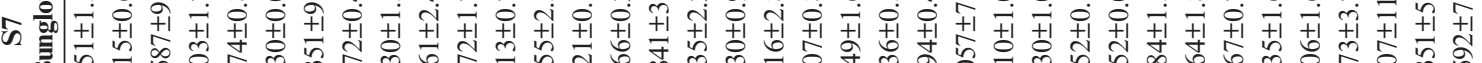

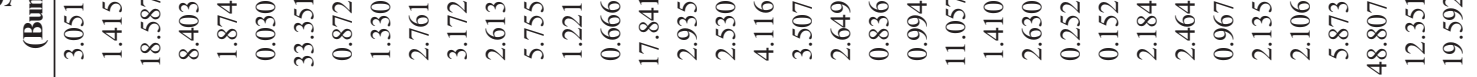
య范

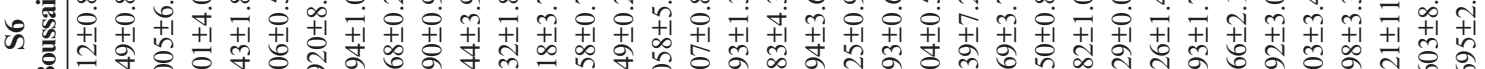

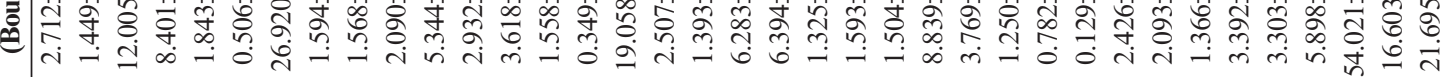

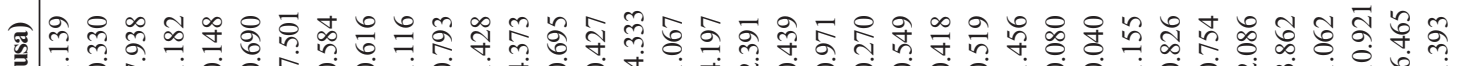

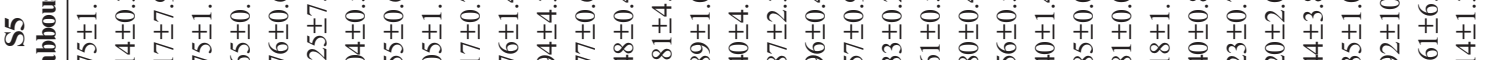

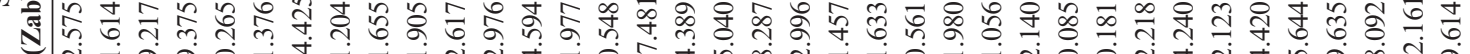

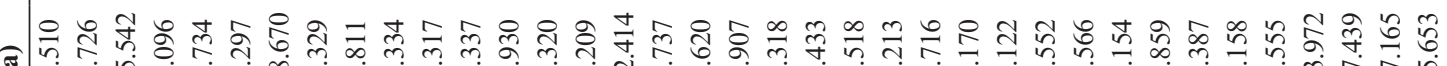
U

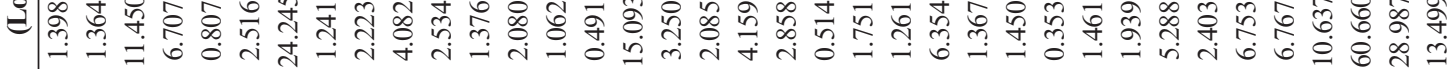

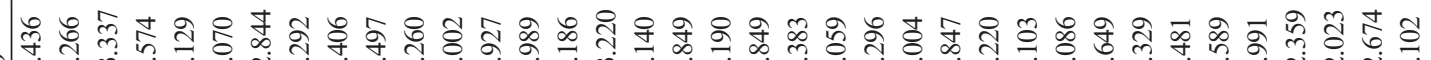
凤

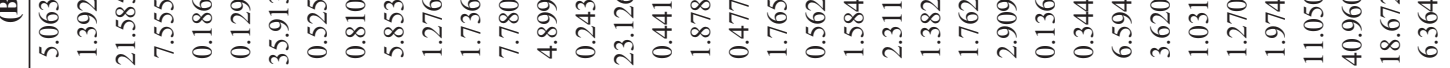

త. 几ు

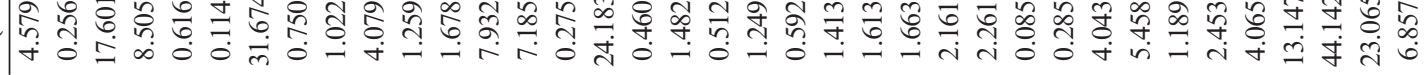

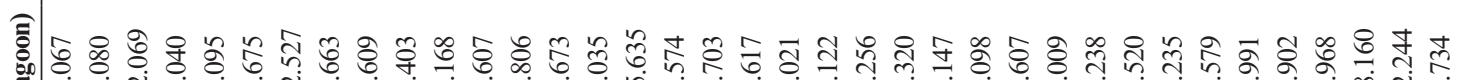

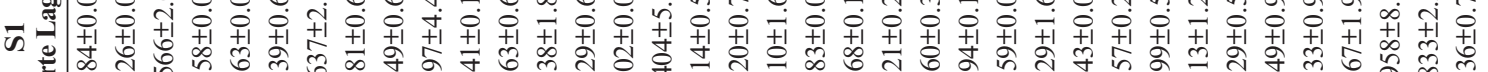

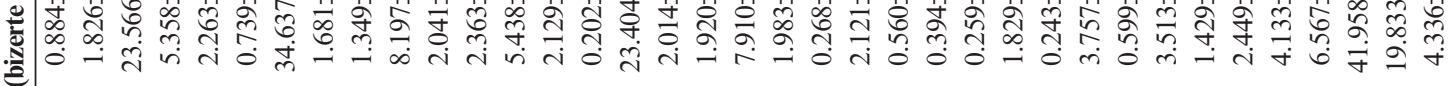

म)

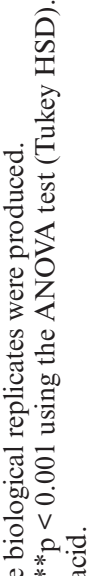

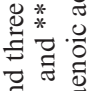

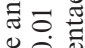
乐 $\mathrm{V}$

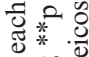
它岤

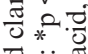
चु)

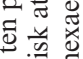

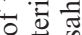

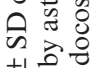

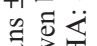
远

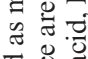

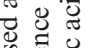
这产高

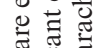

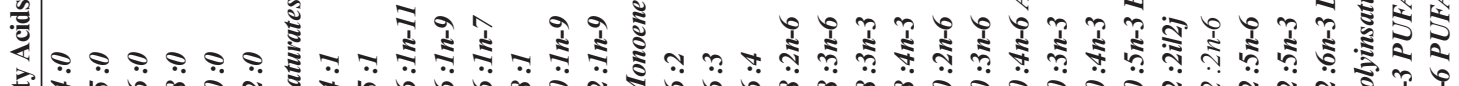

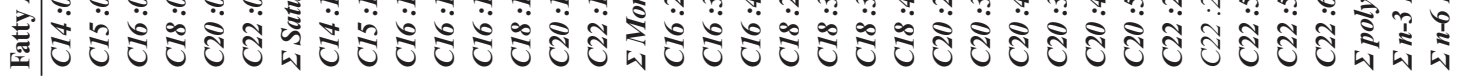


amounts of the specific NMID FA ( $\Sigma \mathrm{C} 22: 2 \mathrm{i} / 2 \mathrm{j})$ found in the clams from S2 (5\%), S4 (5\%) and S5 (4\%) were significantly higher than those found in S9 $(0.8 \%)$ and $\mathrm{S} 10(1 \%)(\mathrm{p}<0.001)$. With regard to the relative participation of the saturated (SFA) and monounsaturated (MUFA) fatty acids, both groups presented lower percentage throughout the study as compared to PUFA $(<35 \%$ and $<29 \%)$. In fact, the maximum amount of SFA was recorded in the clams from $\mathrm{S} 3$ with $35 \%$, but, the minimum was obtained from S9 with $23 \%$ of TFA ( $p<0.05)$. In this context, SFA was dominated by $\mathrm{C} 16: 0$ and $\mathrm{C} 18: 0$ acids ranging from 9 to $23 \%$ and from 4 to $9 \%$ of TFA, respectively $(\mathrm{p}<0.05)$. Concerning MUFA, the main proportion was observed in clams from S9 and S10 $(<24 \%$ of TFA). This group was predominated by C18:1, which varied significantly among the studied stations $(\mathrm{p}<0.001)$. The SIMPER analysis indicated that n-3 PUFA was the main differentiating series due to its elevated presence in the Bizerte (19\%), North Lagoon (23\%), South Lagoon (18\%), Louza (28\%) and Zabbousa (22\%) areas. However, the Boughrara Lagoon and the Zarrat areas were characterized by the lowest percentages of this series $(p<0.05)$. Conversely, the amount of PUFA (n-6) was greater in the Boughrara (S10; 30\%) and Zarrat (S9; 38\%) stations than in Bizerte (S1) and the north Tunisian lagoons (S2, 4\% and S3, $6 \%$, respectively) ( $p<0.001)$.

Multivariate statistical analyses are represented in Figure 3 and Table 3. The FCA analysis separated the stations into three groups. The FCA showed that the first three factors contributed to $63.97 \%$ of the total inertia (factor $1: 36.75 \%$; factor $2: 14.60 \%$ and factor $3: 12.62 \%$ ). The first one (Group A) regrouped the bivalves sampled from the north coast area (S1, S2 and S3) at close to $96.23 \%$, characterized by a higher contribution of $\mathrm{C} 16: 0$, DHA, C14:0, C22:2i/2j, EPA and C16:1-n11 fatty acids at $63.14 \%, 59.17 \%, 44.21 \%, 43.53 \%, 43.53 \%$ and $41.42 \%$; respectively. The specimens from S4, S5, S6, S7 and S8 (Group B; close to 92.14\%) contained an appreciable amount of C20:2n-6, C22:5n-3, C22:5n-6, C16:4n-3, C22:2n-6, C16:2 and C18:3n-6; and explained $90.62 \%, 69.44 \%, 62.70 \%$, $59.90 \%, 47.41 \%, 44.47 \%$ and $40.48 \%$ of group similarity, respectively. Only C18:2n-6 was present in
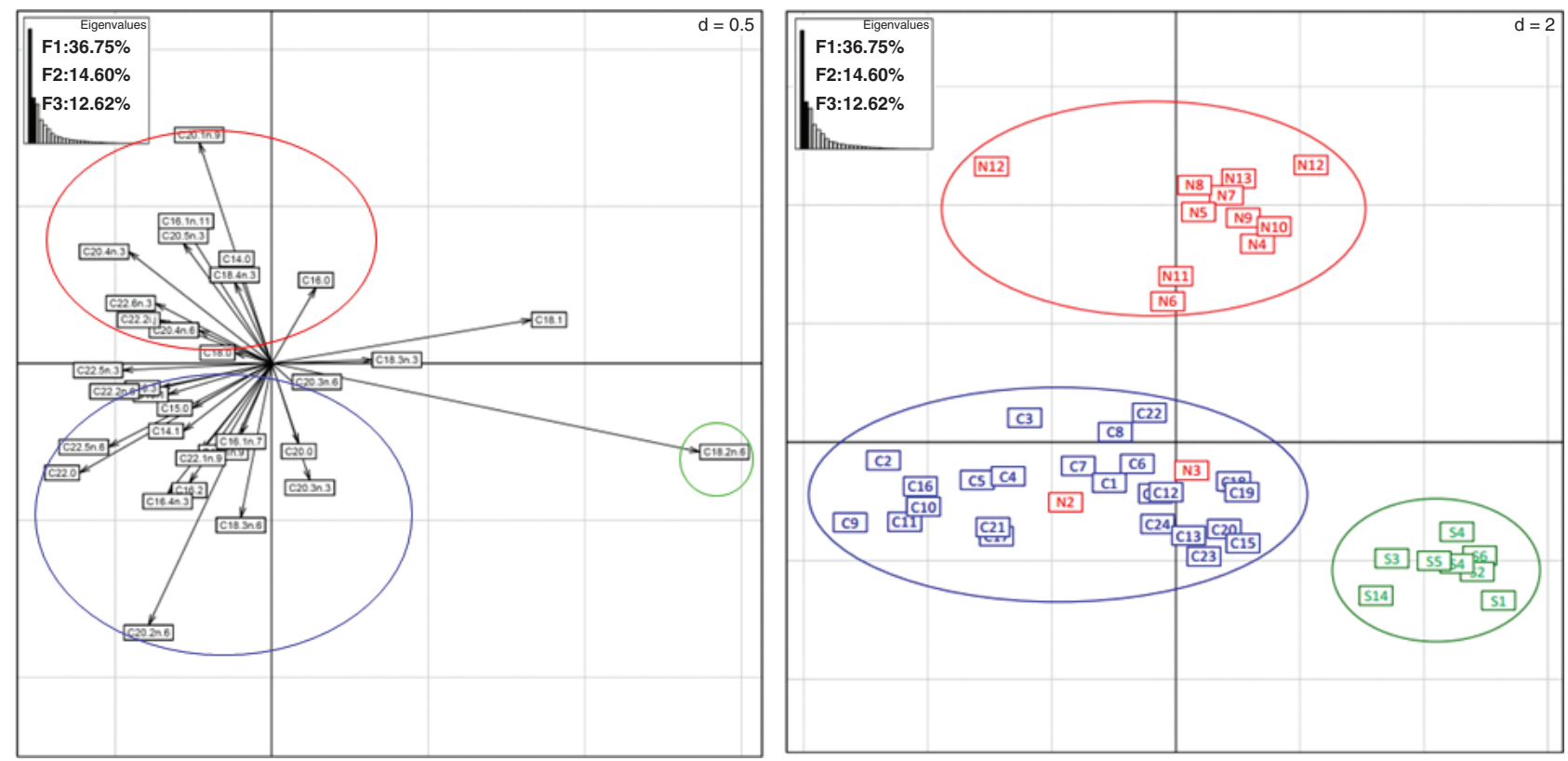

FIGURE 3. Factorial correspondence analysis (FCA) of the fatty acid composition of $V$. decussata sampled along the Tunisian Coast. $\mathrm{N}$ : sites from the north part of Tunisia including Bizerte Lagoon (S1), Chekly (S2) and Baie (S3).

C: sites from the central part of Tunisia including Louza (S4), Zabbousa (S5), Boussaid (S6), Bunglow (S7) and Maoumma (S8). S: sites from the south part of Tunisia including Zarrat (S9) and Boughrara Lagoon (S10).

TABLE 3. Similarity and dissimilarity multi-analysis (PRIMER I) of the fatty acid composition of V. decussata tissues sampled along ten sites from the Tunisian water.

\begin{tabular}{|c|c|c|c|c|c|c|c|c|c|c|c|c|c|}
\hline \multirow{3}{*}{$\begin{array}{l}\text { Variables } \\
\text { Fatty acids }\end{array}$} & \multicolumn{10}{|c|}{ Similarity } & & & \\
\hline & \multicolumn{3}{|c|}{ Group A } & \multicolumn{5}{|c|}{ Group B } & \multicolumn{2}{|c|}{ Group C } & \multicolumn{3}{|c|}{ Dissimilarity } \\
\hline & S1 & S2 & S3 & S4 & S5 & S6 & S7 & S8 & S9 & S10 & Groups A vs B & Group A vs C & Group B vs C \\
\hline Cumulative \% & \multicolumn{3}{|c|}{$96.23 \%$} & \multicolumn{5}{|c|}{$92.14 \%$} & \multicolumn{2}{|c|}{$84.73 \%$} & $74.58 \%$ & $72.62 \%$ & $64.62 \%$ \\
\hline
\end{tabular}


higher amounts in Group $\mathrm{C}$ than the other groups in the order of $97.58 \%$. This group, characterizing $V$. decussata from $\mathrm{S} 9$ and $\mathrm{S} 10$, contained a similarity in FA composition of $84.73 \%$. In Table 3, SIMPER provides a quantitative comparison among sites with a high dissimilarity between groups $(>50 \%)$. The lowest dissimilarity was observed between Groups $\mathrm{B}$ and $\mathrm{C}$ at $64.62 \%$. However, the highest one was detected between Group A and B at 74.58\%.

Non-metric multidimensional scaling was used in this work to better understand the relationship between the lipid compositions of clams and environmental parameters (Figure 4). The total FA composition differed significantly among the sampling sites. The two-dimensional NMDS plot based on the relative presence of different FA and abiotic parameters revealed a clear separation according to their geographical location. The FA composition of the three northern locations appeared particularly close among themselves. The Person correlation analysis revealed significant positive correlations between FA compositions of $V$. decussata collected from the three northern locations and abiotic parameters such as SPM (0.86); S psu (0.99) and Ch a (0.88). A reasonably large amount of variation in the fatty acid compositions and abiotic parameters occurred within each group. In this context, differences were observed among sampling areas and the measured environment variation, in particular, $\mathrm{S}$ psu $(\mathrm{r}=0.22$; $p<0.009)$ and $\mathrm{Ch}$ a $(\mathrm{r}=0.22 ; p<0.01)$ were found to cluster separately in the northern locations from the other one. However, $\mathrm{T}^{\circ} \mathrm{C}(\mathrm{r}=0.48 ; p<0.01)$ was negatively correlated with the two southern locations $(-0.87)$. The other main differentiating variable in

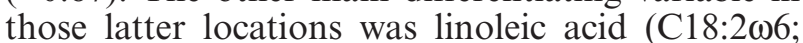
$26 \%$ and $35 \%$ contribution), which was accumulated in high levels in clam tissues from the southern locations. The bi-plot analysis suggested no significant correlation between the FA compositions of the clams collected from the center coast areas and the environmental parameters in this study. However, specimens from the southern region were differentiated from the others groups by $\mathrm{C} 20: 2 \mathrm{n}-6$.

\subsection{Fatty acid trophic markers}

The fatty acid trophic markers are summarized in Table 4. Ten food source indicators were determined in our study, dinoflagellates, diatoms, cyanophytes, bacteria, zooplankton, phytoplankton, detritus,

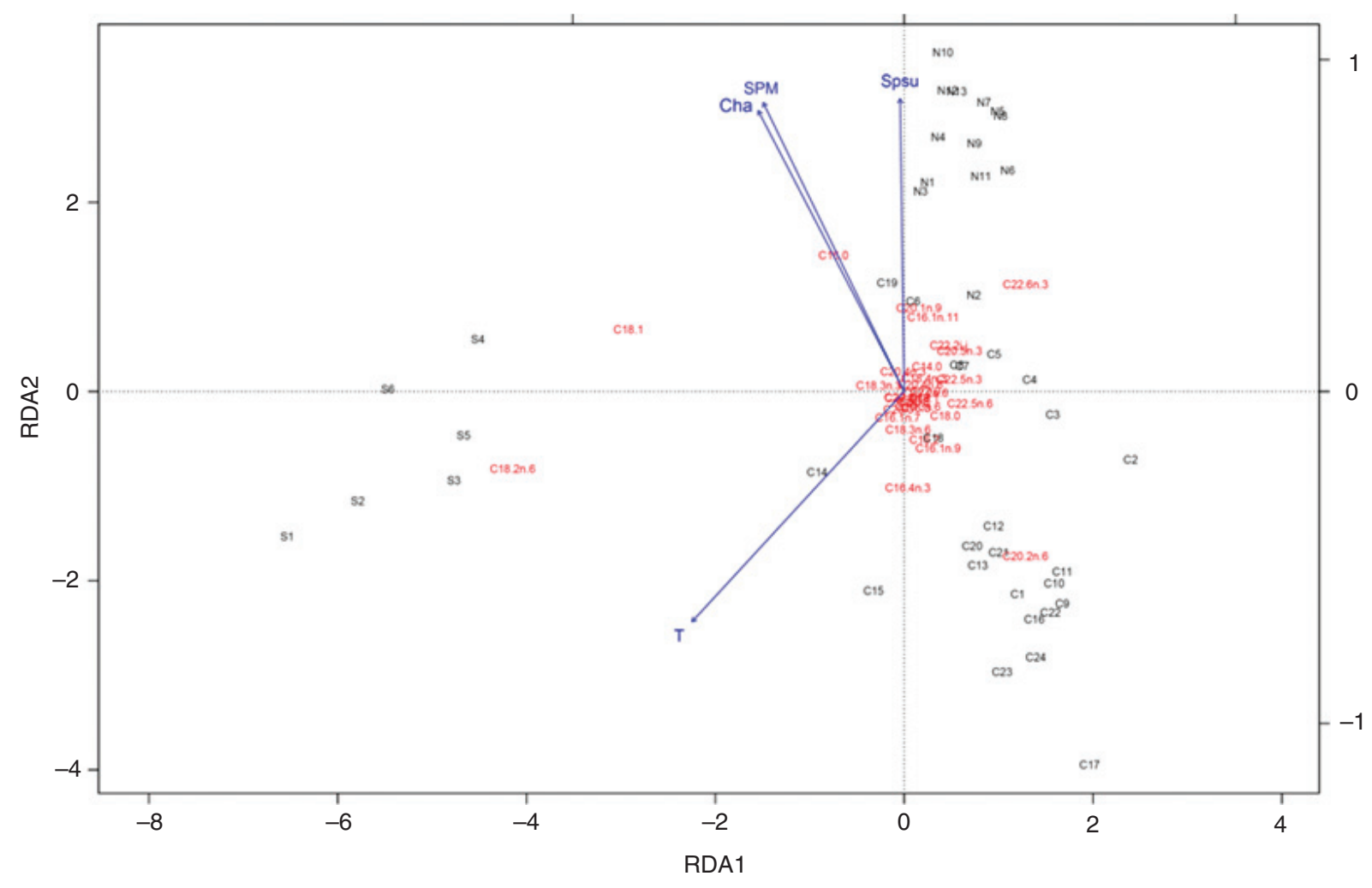

FIGURE 4. Non-metric multidimensional scaling (NMDS) analysis between fatty acid compositions of $V$. decussata and environmental parameters.

$\mathrm{N}$ : sites from the north part of Tunisia including Bizerte Lagoon (S1), Chekly (S2) and Baie (S3).

C: sites from the central part of Tunisia including Louza (S4), Zabbousa (S5), Boussaid (S6), Bunglow (S7) and Maoumma (S8).

S: sites from the south part of Tunisia including Zarrat (S9) and Boughrara Lagoon (S10). SusPended mater (SPM); $\mathrm{T}^{\circ} \mathrm{C}$ (Temperature); Spsu (Salinity); Chlorophyll a (Chl a). 


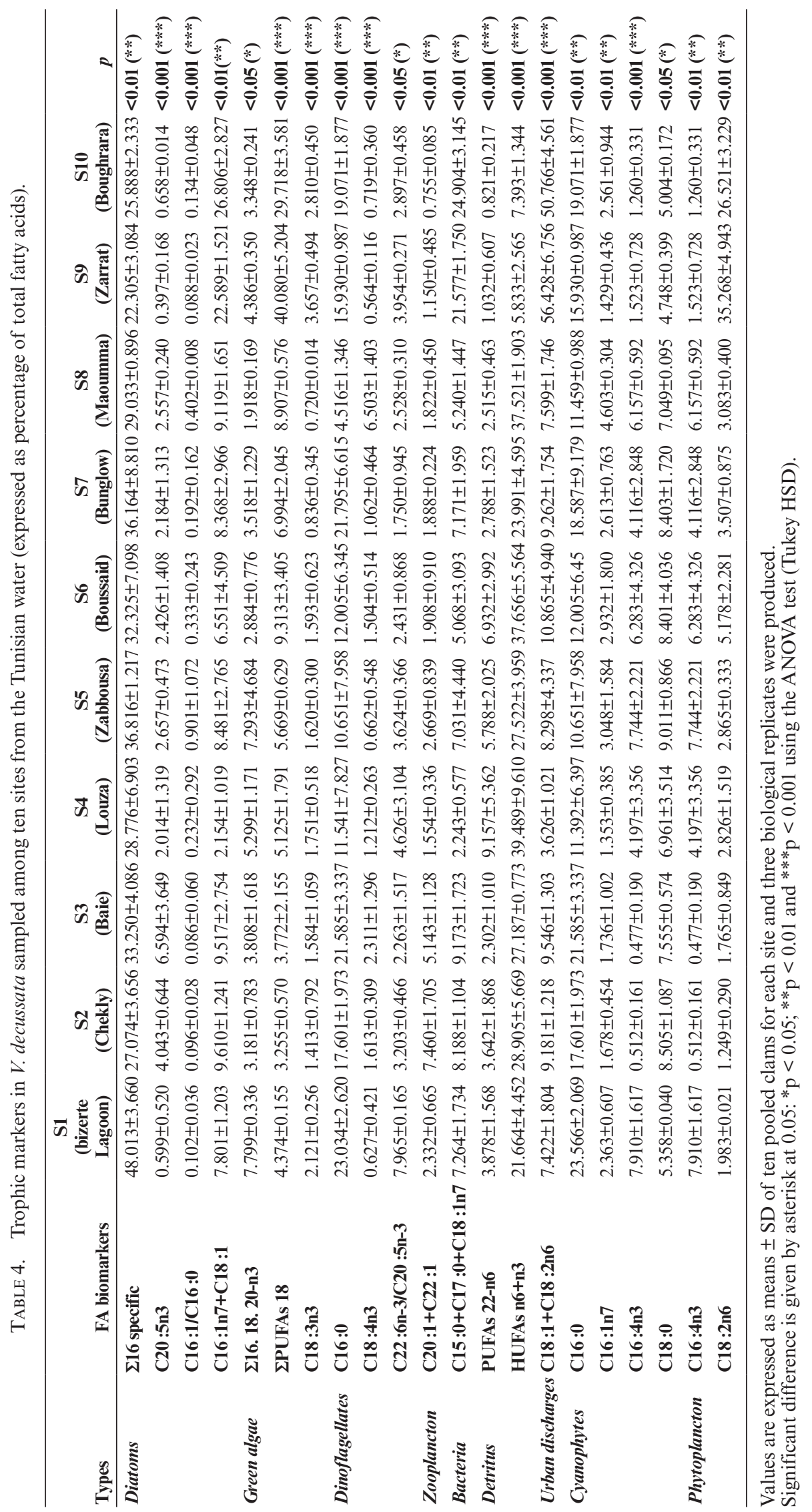

Grasas Aceites 70 (1), January-March 2019, e289. ISSN-L: 0017-3495 https://doi.org/10.3989/gya.0580181 

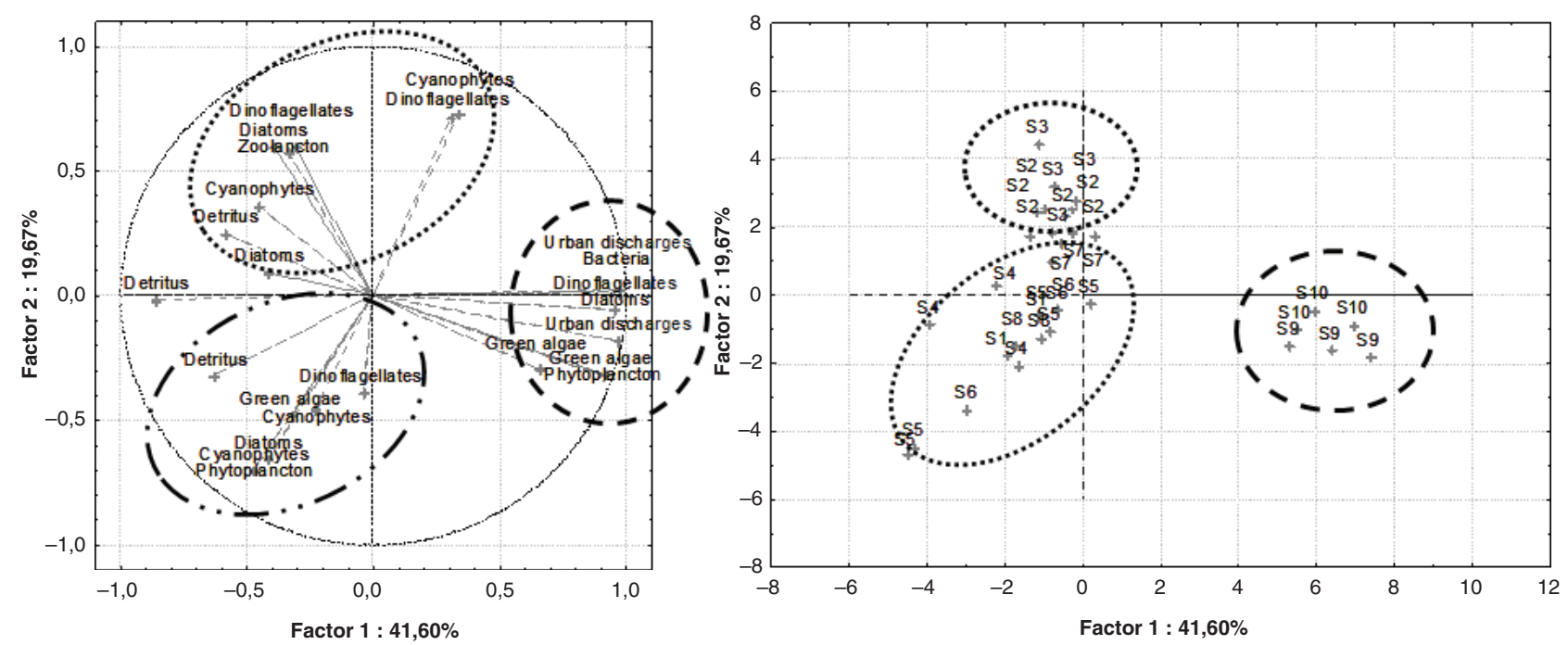

Figure 5. Principal composition analysis (PCA) of trophic markers of $V$. decussata collected along the Tunisian Coast. (A) Correlation circle variables with the factorial axes of trophic markers and (B) individual projections on the factorial design of sampled sites $(1 \times 2)$.

Bizerte lagoon (S1), Chekly (S2), Baie (S3), Louza (S4), Zabbousa (S5), Boussaid (S6), Bunglow (S7), Maoumma (S8), Zarrat (S9) and Boughrara lagoon (S10).

green algae and urban discharge. PCA was applied to the fatty acid trophic marker proportions (Figure 5). A high $\%$ of variability accounted for the two first principal components $(61.26 \%)$. Four indicator food sources of diatoms and dinoflagellates were found in all the $V$. decussata diets. However, green algae and phytoplankton markers characterized clams from all sampled sites except S2 and S3 ( $<<0.01)$. Almost all sites were characterized by cyanophyte diet sources, except for the Southern Tunisian sites (S9 and S10) $(\mathrm{p}<0.01)$. Two urban discharges and one bacteria fatty acid marker were fond with highest proportion in the clams sampled from S9 and S10 ( $p<0.001)$. Detritus markers increased in the $V$. decussata tissues collected from $\mathrm{S} 1, \mathrm{~S} 2, \mathrm{~S} 3, \mathrm{~S} 4, \mathrm{~S} 5$, S6, S7 and S8 $(p<0.05)$. However, the zooplankton marker characterized the diet of the clams sampled from S3 and S2 (p<0.01).

\section{DISCUSSION}

In the present study, the PUFA content in $V$. decussata tissues was present at high values during the sampling period in all stations. PUFA were followed by SFA and then MUFA. These results are in agreement with previous studies carried out on the fatty acid composition of $V$. decussata from other Mediterranean Coasts (Ojea et al., 2004) and of other bivalve species (Boussoufa et al., 2011; Costa et al., 2017) in which the authors showed a selective accumulation of PUFA among the fatty acid groups. MUFA were significantly lower in all stations, except in Boughrara (S10) and Zarrat (S9) where the clams showed similar SFA and MUFA proportions in their tissues. Changes in the PUFA levels were inversely proportional to those of SFA. This result indicates that the unsaturation amount of the FA increased the water temperature was lower. The Pearson correlation test between the water temperature of different stations and the percentage of its n-3 and n-6 PUFA in each group of clams was applied. The results showed that water temperature was negatively correlated with (n-3) PUFA proportions $(p<0.003 ; r=-0.4383)$ and positively correlated with (n-6) PUFA proportions $(p<0.000$; $\mathrm{r}=0.581)$. This might be due to the greater levels of PUFA, which are necessary for maintaining the membrane fluidity of bivalves' cells during colder seasons (Irisarri et al., 2014).

Regarding the FA profile, Louza (S4) clams contained significantly higher amounts of PUFA. However, the lagoon stations (S1, S2, S3 and S10) showed the lowest PUFA proportions. This can be explained by the fact that Louza (S4) was the least polluted station in our coast (Chalgmi et al., 2014) compared to the lagoons, which were highly polluted (Bejaoui et al., 2017) and showed degradation in their PUFA percentages. According to Di Salvatore et al., (2013), a high proportion of PUFA reduces the vulnerability to lipid peroxidation and preserves the proper membrane changeability. Inversely, a reduction in PUFA levels could respond to oxidative damage which can be formed by heightened biotic and abiotic aspects in the ecosystem. The clams from other stations showed a similar distribution in their fatty acid signatures, therefore suggesting the use of similar food sources. In fact, the percent of PUFA recorded in our study was highly correlated with chlorophyll a and suspended matter. This confirms that changes in fatty acid composition are 
strictly linked to available food and high levels of PUFA correspond with good nutritional conditions, as reported by Ojea et al., (2004).

On the other hand, the fatty acid composition of $V$. decussata from the Tunisian Coast presented a prevalence of unsaturated fatty acids (UFA) throughout the study sites. According to many investigations, this higher amount of UFA was specific to a healthy marine species (Ghribi et al., 2018). In fact, the PUFA levels in clam tissues reached their highest values, which coincided with an important amount of $\mathrm{Chl}$ a and lower $\mathrm{T}^{\circ} \mathrm{C}$. Our results suggest that the unsaturation degree increased during the cold season, which maintained membrane fluidity as well as modulating gene expression and the principal keys of eicosanoids (Hochachka and Somero, 2002; Idayachandiran et al., 2014). The change in fatty acid profile of the clams' tissues was influenced by $\mathrm{T}$, which was probably due to the homeoviscous adaptation remodeling membrane lipids by changes in phospholipids, fatty acid and cholesterol contents, as reported previously by Hazel (1995). Our findings corroborate with previous studies carried out on bivalves (Irisarri et al., 2014).

The multivariate analysis of the TFA data, including all samples showed a large difference among regions, explaining a clear north and south distinction along the Tunisian Coastline. Such spatial variation is most likely related to distinct tropical conditions (suspended materials, Chlorophyll a). The FCA analysis of the fatty acid composition was created by two prominent groups. The first was also formed by two sub-groups: The first sub-group included $V$. decussata sampled from the North of Tunisia (group A) (North and Bizerte Lagoons: S1, S2 and S3) characterized by a high proportion of some PUFA fatty acids, such as C22:6n-3. The second group's species were sampled from the center and north-south (group B) coastal waters. This sub-group was characterized by a lower percentage of dissimilarity $(70 \%)$ than the first one. The FA composition of the clams sampled from S10 and S9 showed an independent group (group C) defined mostly by three polyunsaturated FA (C18:2n-6).

Bivalve species living in a shallow depth of the water column were directly influenced by the wide variety of potential food sources such as diatoms, dinoflagellates and zooplankton; and could have further complex trophic variation (Budge et al., 2001). The fatty acid trophic markers used in this study revealed that diatoms and dinoflagellates were the primary incorporated food source of $V$. decussata from the Tunisian Coast. Those two diets are distributed in unequal levels over the sampling stations. In fact, the northern stations were dominated by a high proportion of diatom trophic markers such as sum C16 specific and C20:5n-3. Several studies carried out on some bivalve species showed that the level of C20:5n-3 was mainly derived from diatoms
(Budge et al., 2001). However, the sum of C16:1n$7+\mathrm{C} 18: 1$ indicated that the base diet of diatoms was 2 times higher in the southern station (Zarrat and Boughraralagoon) than in other areas. This unequal geographical dispersion of diatoms was confirmed by several studies showing the differential distribution of diatoms in the northern, central and southern part of Tunisian waters (Feki et al., 2008; Chérif et al., 2011). Concerning dinoflagellate markers, high levels of C16:0 and C18:4n-3 were observed in Bizerte, and the Northern and Southern Lagoons of Tunisia, which were significantly higher in the two southern stations (Gulf of Gabes). Like diatoms, numerous studies approved the geographical distribution of dinoflagellates among the Tunisian waters (Aissaoui et al., 2012). However, the potential difference between diatoms and dinoflagellates was illustrated by the C22:6n-3/C20:5n-3 ratio (Dalsgaad et al., 2003), which varied slightly among sampling sites and marked a significant high proportion in the Bizerte Lagoon. This result may be explained by the abundance of dinoflagellates and the prevalenceof this diet compared to diatoms in this lagoon (Chérif et al., 2011). These findings also suggest that the Bizerte Lagoon has a higher trophic position than the other stations. This position was explained by the high level of suspended mater and chlorophyll a signaled in this area and causing the eutrophication of this lagoon. Furthermore, water temperature, suspended matter, Chlorophyll a, currentology and especially wave amplitudes varied greatly among stations. These abiotic parameters have an important influence on the diet of $V$. decussata in these sites. Considering the difference between lagoon and sea, the wave amplitudes were higher in the coastal area of the Gulf of Gabes (Hattour and Ben Mustapha, 2013) than lagoons such as Bizerte, Boughrara and the North Lagoon of Tunisia. These later were characterized by low hydrodynamics causing water stagnation (Guetat et al., 2012) and then eutrophication of these areas. This phenomenon could generate a physiological stress in bivalves reflected by a passive filter feeding and even an inhibition of the feeding process as a result of shell closure (Wildish and Kristmanson, 2005).

Similar studies carried on bivalves' feeding strategies showed the abundance of diatoms and dinoflagellates in their diet and a preference for dinoflagellates in colder down-welling seasons (Irisarri et al., 2014). The diatom-dinoflagellate ratio was also used in several studies to distinguish among the diet in bivalves from different regions like Coral Sea, New Zealand and Tasmanian areas (Parrish et al., 2015). In this context, Turki, (2004) signaled the presence of 61 species of dinoflagellates in the Bizerte Lagoon versus only 12 species of diatoms. Another typical trophic marker ratio C16:1/C16:0 used to deduce a main diatom versus a dinoflagellate diet (Auel et al., 2002), was followed. In fact, the 
results showed that the levels of $\mathrm{C} 16: 1 / \mathrm{C} 16: 0$ ratios were lower than $1 \%$ in all sampling stations.

In the present study, the highest proportion of C18:2n-6 and C16:4n-3 in the soft tissue of $V$. decussata sampled from the Tunisian waters during winter affirmed the pervasiveness of phytoplancton as a food source. The results showed that the higher proportion of these two trophic markers was observed in clams from S1, S4, S5, S6, S7, S8, S9 and S10 compared to those from S2 and S3. Previous studies have shown that the same fatty acids can be used to suggest the phytoplancton integration of bivalves into wild seafood (Redmond et al., 2010).

The Principal Component Analysis showed a geographical variation in the diet position of clams among sampling sites. Concerning the TFA composition of food sources, clams from S9 and S10 had significantly higher percentages of bacteria markers of (C16 and C18 PUFA), some green algae markers (C15:0 and 18:1n-7), and a lower proportion of diatoms $(\mathrm{C} 20: 5 n-3)$ and dinoflagellate fatty acid markers (C22:6n-3) than from other stations. Further, the increase in bacterial fatty acid markers in the clams from S9 and S10 during the winter was accompanied by a high proportion of the two urban discharge (C18:1 and sum C18:1 + C18:2n-6). In fact, the Boughrara Lagoon (S10) and Zarrat (S9) are well known by their relatively high degrees of pollution (Rabaoui et al.,2013) compared to other southern Tunisian waters. This fact could explain the development of the microbial loops and then their decomposition in these areas. In this context, Fernandez-Jover et al., (2007) showed the usefulness of the determination of fatty acid trophic markers to identify the human impact on an animal's diet.

Herein, results showed a significant abundance of zooplankton in the diet of $V$. decussata sampled from the North Lagoon (S2, S3) as compared to other sampling areas. Our results are in agreement with those reported in several studies showing the abundance of zooplankton in the Gulf of Tunisia (Ben Lamine et al., 2012). Concerning detritus FA indicators, the results showed the abundance of this diet in $V$. decussata sampled from the northern and central Tunisian waters. These specimens were characterized by high proportions of C22: n-6 PUFA and the sum $(n-6+n-3)$ HUFA compared to clams from other stations. Specimens of $V$. decussata from the north and the central stations (Bizerte, Chekly, Baie, Lousa and Zabbousa locations) were characterized by lower percentages of n-6 HUFA than n-3 HUFA. Clams from the southern Tunisian waters were dominated by $n-6$ HUFA compared to n-3 HUFA. Considering that n-6 HUFA was originated from terrestrial organic matter and n-3 HUFA was related to plankton detritus (Alfaro et al., 2006), the clams from the north and center stations are considered to have an important energy source derived from planktonic detritus, compared to those from southern Tunisian waters.

\section{CONCLUSIONS}

This study revealed a significant geographical variation in the fatty acid composition of $V$. decussata related to environmental parameters of ten locations from the Tunisian Coast, thus revealing a good nutritional quality of the species marked by the abundance of PUFA especially DHA and EPA in all the sampled clams. To distinguish the feeding strategies and trophic links of the clam $V$. decussata, a fatty acid trophic marker analysis was conducted in clams from different sites. The results showed a spatial variation in food accessibility for $V$. decussata from the north to the south of the Tunisian coastline. These findings demonstrate that the FA signature can provide considerable information on the feeding strategy and the living condition of native $V$. decussata which can be used to discriminate among populations.

\section{ACKNOWLEDGMENTS}

This work was supported by the Physiology and Aquatic Environment Laboratory, Faculty of Sciences, University of Tunis El Manar. We would like to thank all the team of this laboratory, especially Mr. Hssan Mejri for his technical assistance with the gas chromatography analysis.

\section{DISCLOSURE}

The authors declare no conflict of interest.

\section{REFERENCES}

Aissaoui A, Turki S, Ben Hassine OK. 2012. Occurrence of harmful dinoflagellates in the Punic harbors of Carthage Gulf of Tunis and their correlations with the physicochemical parameters. Bull. Instit. Nati. Scien. Techn. Mer 39, 127-148. ISSN:0330-0080.

Albergamo A, Rigano F, Purcaro G, Mauceri A, Fasulo S,Mondello L. 2016. Free fatty acid profiling of marine sentinels by nanoLC-EI-MS for the assessment of environmental pollution effects. Sci. Total Environ. 571, 955-962. https://doi.org/10.1016/j.scitotenv.2016.07.082

Alfaro AC 2006. Evidence of cannibalism and bentho-pelagic coupling within the life cycle of the mussel, Perna canaliculus. J. Exp. Mar. Biol. Ecol. 329, 206-217. https://doi. org/10.1016/j.jembe.2005.09.002

Aminot A. Chaussepied C. 1983. Manuel des analyses chimiques en milieu marin. In Brest CNEXO ed. Centre national d'exploitation des océans, France, 400p.

Auel H, Harjes M, De Rocha R, Stübing D, Hagen W, 2002. Lipid biomarkers indicate different ecological niches and trophic relationships of the Arctic hyperiid amphipods Themisto abyssorum and Themisto libellula. Pol. Bio. 25, 374-383.

Bejaoui S, Boussoufa D, Tir M, Gharsallah-Houas I, Ghram A, El Cafsi M, Soudani N. 2017. DNA damage and oxidative stress in digestive gland of Venerupis decussata, collected from two contrasting habitats in the southern Tunisian coast: Biochemical and histopathological studies. Cah. Bio. Mar. 58, 123-135. https://doi.org/10.21411/ CBM.A.133C71C1

Ben Lamine Y, Daly YKO, Daly YN. 2012. Planktonic copepod community in the nertic area south western part of Tunis 
bay influenced by Meliane river supplies (South western Mediterranean Sea). Bull. Instit National. Scien. Techno. Mer. 39, 141-147. ISSN 330-80

Boussoufa D, Ghazali N, Viciano E, Navarro JC, EL Cafsi M. 2011. Seasonal variation in condition and fatty acid composition of coquina clam, Donax trunculus (Linnaeus 1758) (Mollusca: Bivalvia) from the Tunisian coast. Cah. Bio. Mar. 52, 47-56.

Budge SM, Prrish CC, Mckenzie CH. 2001. Fatty acid composition of phytoplankton, settling particulate matter and sediments at a sheltered bivalves aquaculture site. Mar. Chem. 76, 285-303. https://doi.org/10.1016/ S0304-4203(01)00068-8

Budge SM, Iverson SJ, Koopman HN. 2006. Studying trophic ecology in marine ecosystems using fatty acids: a primer on analysis and interpretation. Mar. Mamm. Sci. 22, 759-801. https://doi.org/10.1111/j.1748-7692.2006.00079.x

Capillo G, Silvestro S, Sanfilippo M, Fiorino E, Giangrosso G, Ferrantelli V, Vazzana I, Faggio C. 2018. Assessment of Electrolytes and Metals Profile of the Faro Lake (Capo Peloro Lagoon, Sicily, Italy) and Its Impact on Mytilus galloprovincialis. Chem. Biodivers. 15, e1800 D44. https://doi. org/10.1002/cbdv.201800044

Chalghmi H, Bourdineaud JP, Haouas Z, Gourves PY, Zrafi I, Saidane-Mosbahi D. 2014. Transcriptomic, Biochemical, and Histopathological Responses of the Clam Ruditapes decussatus from a Metal-Contaminated Tunis Lagoon. Arch. Environ. Contam. Toxicol. 70, 241-56. https://doi. org/10.1007/s00244-015-0185-0

Cecchi G, Basini S, Castano C. 1985. Méthanolyse rapide des huiles en solvant. R. Franc. Corps Gras 4.

Chérif W, El Bour M, Daly YKO. 2011. Screening de l'activité anti microfouling d'algues verts récoltées sur la côte nord Tunisienne. Bull. Instit. Nat. Sci. Techn. Mer. 38, 131-138. ISSN 0330-0080.

Costa R, Albergamo A, Piparo M, Zaccone G, Capillo G, Manganaro A, Mondello L. 2017. Multidimensional gas chromatographic techniques applied to the analysis of lipids from wild-caught and farmed marine species. Eur. $J$. Lipid. Sci. Technol. 119, 1600043. https://doi.org/10.1002/ ejlt.201600043

Dalsgaard J, John M, Kattner G, Muller-Navarra D, Hagen W. 2003. Fatty acid trophic markers in the pelagic marine environment. Adv. Mar. Biol. 46, 225-340. https://doi. org/10.1016/S0065-2881(03)46005-7

Desvilettes CH, Bourdier G, Amblard CH,Barth B. 1997a. Use of fatty acids for the assessment of zooplankton grazing on bacteria, protozoans and microalgae. Fresh. Water. Biol. 38, 629-637. https://doi.org/10.1046/j.1365-2427.1997.00241.x

Fanelli E, Papiol V, Cartes JE, Rumolo P, Lopez-Pèrez C. 2013. Trophic webs of deep megafauna on mainland and insular slopes of the NW Mediterranean: a comparision by stable isotope analysis. Mar. Ecol. Prog. Ser. 490, 199-221. https://doi.org/10.3354/meps10430

Fernandez-Jover D, Jimenez JAL, Sanchez-Jerez P, BayleSempere J, Casalduero FG, Lopez FJM, Dempster T. 2007. Changes in body condition and fatty acid composition of wild Mediterranean horse mackerel (Trachurus mediterraneus, Steindachner, 1868) associated to sea cage fish farms. Mar. Environ. Res. 63, 1-18. https://doi.org/10.1016/j. marenvres.2006.05.002

Feki W, Hamza A, Bel Hassen M, Rebai A. 2008. Les efflorescences phytoplanctoniques dans le golfe de gabes (Tunisie) au cours de dix ans de surveillance (1995-2005). Institut National des Sciences et Technologies de la Mer 35, $105-116$.

Folch J, Lees M, Stanley GHS. 1957. A simple method for the isolation and purification of total lipids from animal tissues. J. Biol. Chem. 226, 497-509.

Gomes T, Albergamo A, Costa R, Mondello L, Dugo G. 2017. Potential use of proteomics in shellfish aquaculture: from assessment of environmental toxicity to evaluation of seafood quality and safety. Cur. Org. Chem. 21, 402-425. https://doi.org/10.2174/1385272820666161102121232

Ghribi F, Boussoufa D, Aouini F, Bejaoui S, Chetoui I, Rabeh I, El Cafsi M. 2018. Seasonal variation of biochemical composition of Noah's ark shells (Arca noae L. 1758) in a Tunisian coastal lagoon in relation to its reproductive cycle and environmental conditions. Aquat. Living Resour. https://doi.org/10.1051/alr/2018002

Guetat F, Sellem F, Akrout F, Brahim M, Atoui A. 2012. Etat environnemental de la lagune de Boughrara et ses alentours deux ans apres les travaux d'amenagement et d'elargissement du pont d'El Kantra. Bull. Inst. Natn. Scien. Tech. Mer de Salammbô, v39. ISSN: 0330-0080.

Hamida L, Medhioub M, Cochard JC, Romdhane M, Le Pennec M. 2004. A comparative study of the reproductive cycle of Ruditapes decussatus under natural (South of Tunisia) and controlled conditions (hatchery). Cah. Biol. Mar. 45, 291-303.

Hattour A, Ben Mustapha A. 2013. Le couvert vegetal matin du golf de gabes: cartographie et réseau de surveillance de l'herbier de posidonie. Bull. Instit. Nat. Sci. Techn. Mer. $164 \mathrm{pp}$.

Hazel JR. 1995. Thermal adaptation in biological membranes: is homeoviscous adaptation the explanation? Annu. Rev. Physiol. 57, 19-42.

Hochachka PM, Somero GN. Biochemical adaptation. Mechanism and process in physiological evolution, Princeton University Press, Oxford, 2002, 480 p.

Idayachandiran G, Muthukumar A, Kumaresan S, Balasubramanian T. 2014. Nutritional Value of Marine Bivalve, Donax cuneatus 86 (Linnaeus, 1758) from Cuddalore Coastal Waters, Southeast Coast of India. Inventi Impact Life Style 1, 15-19.

Irisarri J, Fernandez-Reiriz MJ, Cranford PJ, Labarta U. 2014. Effects of seasonal variation in phytoplankton on the bioenergetic responses of mussels (Mytilus galloprovincialis) held on a raft in the proximity of rea sea bream (Pagellus bogaraveo) net-pens. Aqua. 428-429, 41-53. https://doi. org/10.1016/j. aquaculture.2014.02.030

Kharlamenko IV, Wurzberg L, Peters J, Borisovets EE. 2015. Fatty acid compositions and trophic relationships of shelled molluscs from the kuril-Kamchatka Trench and the adjacent abyssal plain. Deep-sea.Res. II 111, 389-398. https://doi.org/10.1016/j.dsr2.2014.09.002

Leveillé JC, Amblard C, Bourdier G. 1997. Fatty acids as specific algal markers in a natural lacustrian phytoplankton. J. Plankton. Res. 19, 469-490. https://doi.org/10.1093/ plankt/19.4.469

Li R, Watanabe MM. 2001. Fatty acid profiles and their chemotaxonomy in planktonic species of Anabaena (Cyanobacteria) with straight trichomes. Phytoch. 57, 727731. https://doi.org/10.1016/S0031-9422(01)00082-6

McLusky SD, Elliott M. 2004. The Estuarine Ecosystem: Ecology, threats and management. University press Third Edition, Oxford.

Natalotto A, Sureda A, Maisano M, Spanò N, Mauceri A, Deudero S. 2015. Biomarkers of environmental stress in gills of Pinna nobilis (Linnaeus 1758) from Balearic Island. Ecotoxical. Environ. Saf. 122, 9-16. https://doi. org/10.1016/j.ecoenv.2015.06.035

Ojea J, Pazos AJ, Martinez D, Novoa S, Sanchez JL, Abad M. 2004. Seasonal variation in weight and biochemical composition of the tissues of Ruditapes decussatus in relation to the gametogenic cycle. Aqua. 238, 451-468. https://doi. org/10.1016/j.aquaculture.2004.05.022

Pagano M, Capillo G, Sanfilippo M, Palato S, Trischitta F, Manganaro A, Faggio C. 2016. Evaluation of Functionality and Biological Responses of Mytilus galloprovincialis after Exposure to Quaternium-15 (Methenamine 3-Chloroallylochloride). Molecules 21, 144. https://doi. org/10.3390/molecules 21020144

Parrish CC, Pethybridge H, Young JW, Nichols PD. 2015. Spatial variation in fatty acid trophic markers in albacore tuna from the southwestern Pacific Ocean-A potential 'tropicalization' signal. Deep. sea. Rea. II 113, 19-207. https://doi.org/10.1016/j.dsr2.2013.12.003

Pernet F, Malet N, Pastoureaud A, Vaquer A, Quéré C, Dubroca L. 2012. Marine diatoms sustain growth of bivalves in a Mediterranean lagoon. J. Sea. Res. 68, 20-32. https://doi. org/10.1016/j.seares.2011.11.004 
Prato E, Danieli A, Maffia M, Biandolino F. 2010. Lipid and Fatty Acid Compositions of Mytilus galloprovincialis Cultured in the Mar Grande of Taranto (Southern Italy): Feeding Strategies and Trophic Relationships. Zool. Stu. 49, 211-219.

Rabaoui L, Balti R, El Zrelli R, Tlig-Zouari S. 2013. Assessment of heavy metal pollution in the gulf of Gabes (Tunisia) using four mollusc species. Med. Mar. Sci. 15. https://doi. org $/ 10.12681 / \mathrm{mms} .504)$

Redmond KJ, Magnesen T, Hansen PK, Strand O, Meier S. 2010. Stable isotopes and fatty acids as tracers of the assiilation of salmon fish feed in blue mussels (Mytilus edulis). Aqua. 298, 202-210. https://doi.org/10.1016/j. aquaculture.2009.10.002

Rocchetta I, Pasquevich MY, Heras H, De Molina MDCR, Luquet CM. 2014. Effetcs of sewage discharges on lipid and fatty acid composition of the Patagonian bivalve Diplodon Chilensis. Mar. Poll. Bull. 79, 211-219. https:// doi.org/10.1016/j.marpolbul.2013.12.011

Sakdullah A, Tsuchiya M. 2009. The origin of particulate organic matter and the diet of tilapia from an estuarine ecosystem subjected to domestic wastewater discharge: fatty acid analysis approach. Aqua. Ecol. 43, 577-589. https://doi.org/10.1007/s10452-008-9195-6

Salvatore P di, Calcagno JA, Ortiz N, De Molina MDCR, Sabatini SE. 2013. Effect of seasonality on oxidative stress responses and metal accumulation in soft tissues of Aulacomya atra, a mussel from the south Atlantic Patagonian coast. Mar. Environ. Res. 92, 244-252. https:// doi.org/10.1016/j.marenvres.2013.10.004

Turki S. 2004. Suivi des microalgues planctoniques toxiques dans les zones de production, d'élevage des mollusques bivalves et d'exploitation des oursins du nord de la tunisie. Bull. Instit. Nat. Sci. Techn. Mer. 31, 83-96.

Wang S, Jin B, Qin H, Sheng Q, Wu J. 2015. Trophic Dynamics of Filter Feeding Bivalves in the Yangtze Estuarine Intertidal Marsh: Stable Isotope and Fatty Acid Analyses. PLOS 10, e0135604. https://doi.org/10.1371/ journal.pone. 0135604

Wildish D, Kristmanson D. 2005. Benthic suspension feeders and flow. Cambridge University, New York. 